\title{
Scenario forecasting changes in the water balance components of the Olenek and lindigirka river basins due to possible climate change
}

\author{
Ye. M. Gusev, O. N. Nasonova, L. Ya. Dzhogan, and E. E. Kovalev \\ Institute of Water Problems, Russian Academy of Sciences, Moscow, Russia \\ Correspondence to: Ye. M. Gusev (sowaso@yandex.ru)
}

Received: 11 March 2015 - Accepted: 11 March 2015 - Published: 12 June 2015

\begin{abstract}
Scenario projections of the dynamics of meteorological characteristics for the basins of the Olenek and Indigirka rivers (the Republic of Sakha) in the XXI century have been obtained for four IPCC global climate change scenarios of SRES family which correspond to specified scenarios of economic, technological, political, and demographic development of human civilization. The projections have been used to calculate scenarios of possible changes in water balance components for the basins under consideration up to the year of 2063 . The calculation procedure involves a physically-based model for heat and mass exchange between the land surface and the atmosphere SWAP and climate scenario generator MAGICC/SCENGEN.
\end{abstract}

\section{Introduction}

As noted in different Technical documents of the IPCC, climate changes, if they occur, will cause the fastest and deepest response in polar regions, which largely control the hydrological processes and water resources. Considering the role of rivers of the pan-Arctic basin in transport of heat, sediments, pollutions and biogenic substances northward, the environmental changes caused by changes in climate can have a considerable effect on the fresh water balance of the Arctic Ocean, on the influx of the above substances into it, on the formation of sea ice, and, eventually, on the thermohaline circulation and global climate.

The objective of the present study is to estimate possible changes in the water balance components in the Olenek and the Indigirka river basins (situated in Yakutia, the Sakha Republic, under the most severe meteorological conditions of Eurasia) resulting from different climate change scenarios.

\section{Study river basins}

The main features of both river basins are extremely low winter temperatures and permafrost.

The Olenek River basin is situated in the northwestern Yakutia northward from the polar circle (between 106 and $126^{\circ}$ E) (Fig. 1). The river originates on the slopes of Yangkan Mountain and empties into Olenekskii Bay of the Laptev Sea. The river basin area is nearly $220000 \mathrm{~km}^{2}$. The climate of the basin is sharply continental with air temperature ranging from very low values in winter (with minimum of -60 to $-55^{\circ} \mathrm{C}$ ) to high in summer (up to 20 $30^{\circ} \mathrm{C}$ ). Cyclonic activity in summer results in the maximal precipitation (nearly $300 \mathrm{~mm}$ ), while in winter precipitation decreases to $35-45 \mathrm{~mm}$. Soils are mostly gley, permafrosttaiga and peaty bog. The vegetation is represented by mosslichen-suffruticose tundra in the north and larch northerntaiga scarce forest in the middle and southern parts of the basin.

The Indigirka River basin is located between 62 and $72^{\circ} \mathrm{N}$ and 136 and $151^{\circ} \mathrm{E}$ (Fig. 1). Its area is about $360000 \mathrm{~km}^{2}$. Air temperature is very low in winter (minimal values varies from -65 to $-50{ }^{\circ} \mathrm{C}$ ) and high in summer (up to $20-35^{\circ} \mathrm{C}$ ). The annual precipitation ranges from $250 \mathrm{~mm}$ on the coast to $600 \mathrm{~mm}$ in mountains. Precipitation mostly falls during warm season. The cold-season precipitation equals to $35-45 \mathrm{~mm}$. A characteristic feature of vegetation is predominance of larch forests in the forest zone. A zone of arctic deserts and a zone of moss-lichen tundra are situated in the northern part of the basin. 


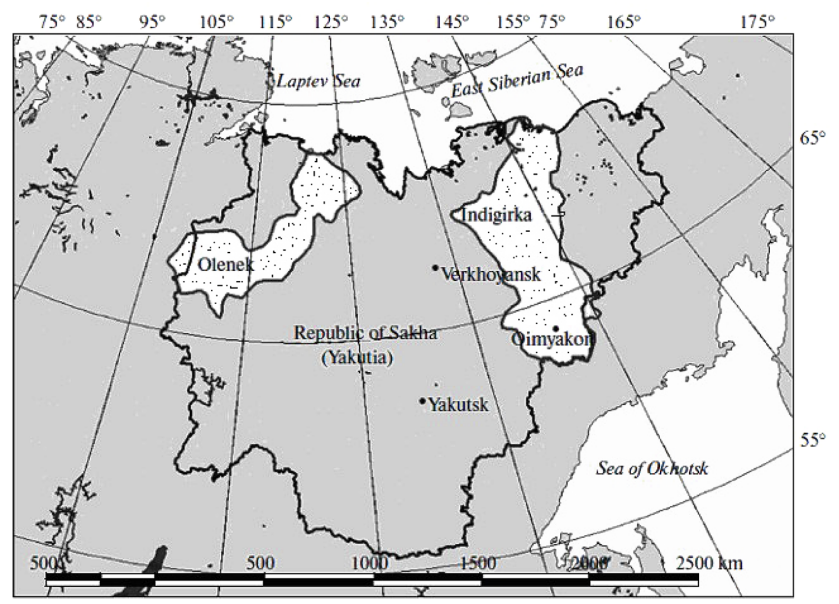

Figure 1. Location of the Olenek and the Indigirka River basins.

\section{The method of scenario prediction of changes in water balance components in northern river basins in the context of anticipated climate change}

The problem formulated in the paper is solved with the use of a method developed in (Gusev and Nasonova, 2013). It is based on the land surface model Soil Water-AtmospherePlants (SWAP) (Gusev and Nasonova, 2010), global datasets of land surface parameters, and scenario projections of changes in meteorological variables during the XXI century.

The SWAP model is based on a physically-based treatment of heat and water exchange in the ground water - soilplant/snow cover - near-surface atmospheric layer system and the description of runoff hydrograph transformation due to water motion over surface elements of the river basin toward the channel network and within the channel network. The territory of both basins is schematized as a set of calculational $1^{\circ} \times 1^{\circ}$ grid cells, interconnected by river channel network. The schematization of the basins of the Olenek and the Indigirka rivers is given in (Gusev et al., 2013).

The forcing data for the SWAP model include $3 \mathrm{~h}$ nearsurface meteorology (incoming longwave and shortwave radiation, air temperature and humidity, precipitation, wind speed, air pressure) for each calculational grid cell. The land surface parameters (soil and vegetation characteristics) for each grid cell were taken from global datasets (Zhao and Dirmeyer, 2003), slightly modified in (Gusev et al., 2008). The key model parameters were optimized using the SCEUA optimization algorithm (Duan et al., 1992) to increase the accuracy of runoff simulation. The results of parameter optimization for the Olenek and the Indigirka basins are given in (Gusev et al., 2013).

Scenarios of the dynamics of meteorological variables in the XXI century were created with the help of a climate scenario generator MAGICC/SCENGEN (Wigley et al., 2000)

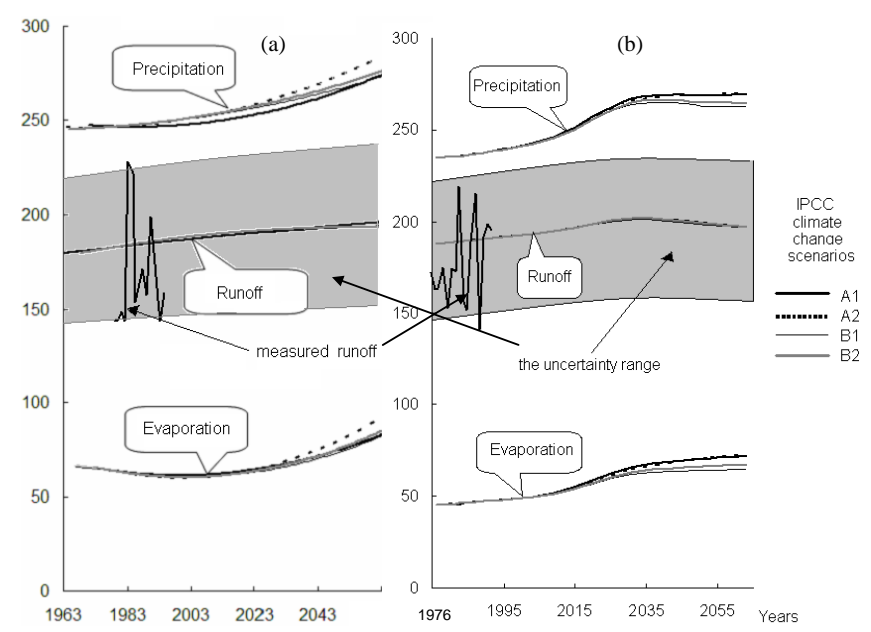

Figure 2. Changes of climatic (averaged over 22-24 years) annual precipitation, runoff, and evapotranspiration, $\mathrm{mm}$, in the Indigirka River (a) and the Olenek River (b) basins by 2063 according to the SRES climate change scenarios A1, A2, B1, and B2, as well as measured annual runoff for the same rivers.
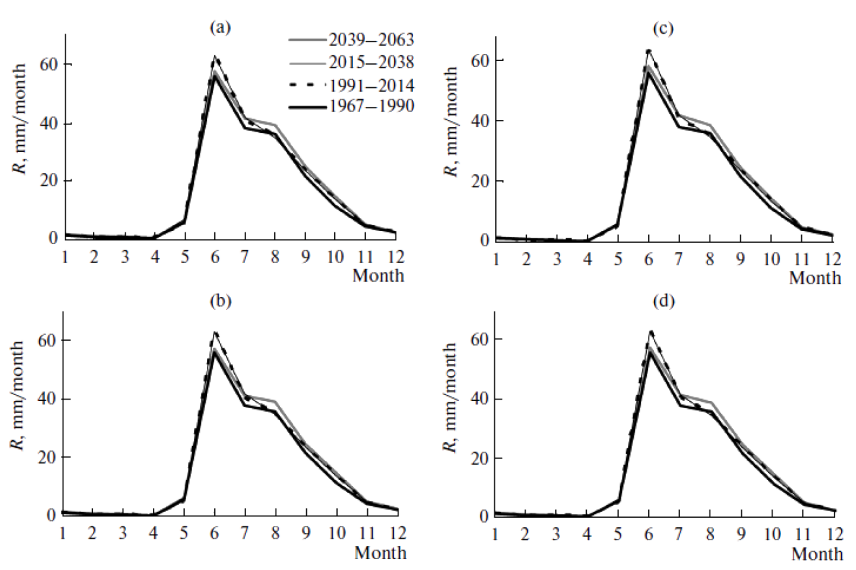

Figure 3. Changes in monthly values of the annual climatic hydrograph of the Indigirka River from 1967 to 2063 according to the SRES scenarios: (a) A1, (b) A2, (c) B1, and (d) B2.

for four IPCC global climate scenarios of SRES (Special Report on Emissions Scenarios) family: A1, A2, B1, B2 (Nebojsa et al., 2000), corresponding to specified scenarios of economic, technological, political, and demographic development of human civilization. Then a disaggregation procedure (Gusev and Nasonova, 2013) was used to convert the obtained monthly values of meteorological variables to threehour values for the period of 2000-2063 for both rivers.

The obtained dynamics of three-hour meteorological data were used as inputs to SWAP to simulate water regime characteristics in the Olenek basin from 1976-2063 and in the Indigirka basins from 1967-2063 for all four climate scenarios. Herewith, meteorological data in the Olenek basin from 1976-1999 and in the Indigirka basin from 1967-1999 were 

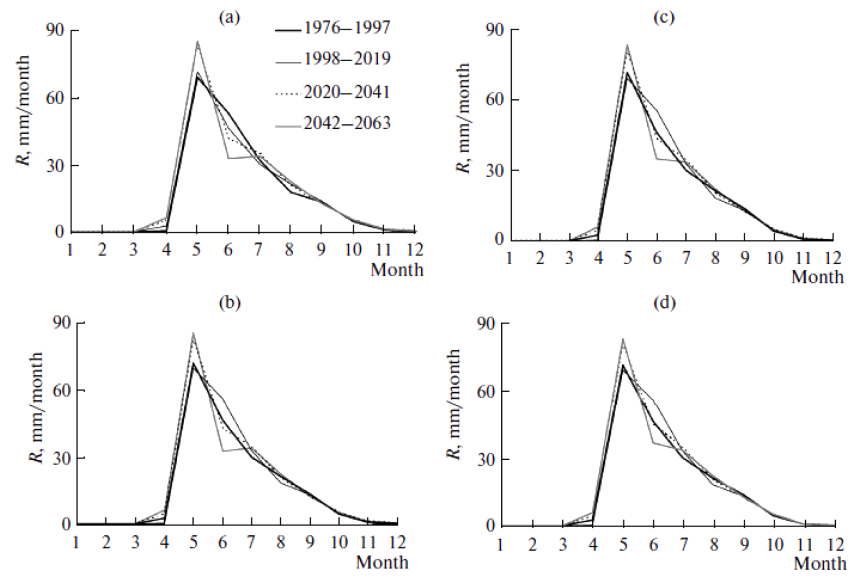

Figure 4. Changes in monthly values of the annual climatic hydrograph of the Olenek River from 1976 to 2063 according to the SRES scenarios: (a) A1, (b) A2, (c) B1, and (d) B2.

taken from observations at meteorological stations. To obtain climate-scale characteristics, the results of calculations were averaged over four time intervals: 1967-1990, 19912014, 2015-2038, and 2039-2063 for the Indigirka River and 1976-1997, 1998-2019, 2020-2041, and 2042-2063 for the Olenek River.

\section{Results}

Figure 2 gives the dynamics of calculated climatic (averaged over the time intervals indicated above) annual precipitation, evapotranspiration, and river runoff for all four SRES climate change scenarios for the Olenek and the Indigirka basins, respectively. As can be seen from Fig. 2, the results of calculations for all SRES scenarios differ insignificantly.

Figure 2 also shows the boundaries of uncertainties of $95 \%$-probability for the simulated river runoff. Uncertainty of runoff, caused in this work only by the structural instability of the atmosphere due to its initial conditions (climatic noise), was determined on the basis of 45 SWAP model simulations with different initial state of the atmosphere on 1 July 1979. Meteorological forcing data to drive the SWAP were obtained using the atmospheric general circulation model ECHAM5. In so doing the technique developed in (Semenov et al., 2010) was used. A series of measured annual (non-climatic) river runoff, also presented in Fig. 2 for each river, shows that annual values of measured runoff are within the calculated uncertainty intervals.

Let us consider variations in the dynamics of annual climatic runoff hydrographs, i.e. hydrographs averaged over the time intervals, which slightly differ for the two rivers (Figs. 3, 4). As can be seen from Fig. 3, the shape of climatic hydrograph for the Indigirka almost does not change over time. The climatic hydrograph of the Olenek River changes more significantly (Fig. 4).

\section{Conclusions}

Scenario projections of the dynamics of water balance components for the Olenek and the Indigirka river basins, obtained for four SRES climate change scenarios, have shown that the realization of all scenarios will result in an increase in all water balance components, including precipitation, evapotranspiration, and river runoff, in both basins by 2063 . The quantitative difference between four projections of each water balance component is relatively small. It is also shown that climatic noise (related to natural variability of climate system resulting from stochastic nature of atmospheric dynamics), which determines a lower limit of uncertainty that can be reached in climate system modeling, also determines a lower level of uncertainty in the assessment of characteristics of hydrological system.

Acknowledgements. The study was supported by the Russian Science Foundation (grant no. 14-17-00700).

\section{References}

Duan, Q., Sorooshian, S., and Gupta, V. K.: Effective and efficient global optimization for conceptual rainfall runoff models, Water Resour. Res., 28, 1015-1031, 1992.

Gusev, E. M. and Nasonova, O. N.: Modelling heat- and water exchange between land surface and atmosphere. Nauka, Moscow, Russia, 328, 1-328, 2010 (in Russian).

Gusev, E. M. and Nasonova, O. N.: A Technique for Scenario Prediction of Changes in Water Balance Components in Northern River Basins in the Context of Possible Climate Change, Water Res., 40, 426-440, 2013.

Gusev, E. M., Nasonova, O. N., Dzhogan, L. Ya., and Kovalev E. E.: The Application of the Land Surface Model for Calculating River Runoff in High Latitudes, Water Res., 35, 171-184, 2008.

Gusev, E. M., Nasonova, O. N., Dzhogan, L. Ya., and Aizel', G. V.: Modeling Streamflow of the Olenek and Indigirka Rivers Using Land Surface Model SWAP, Water Res. 40, 535-543, 2013.

Nebojsa, N., Alcamo, J., J., Davis, G., de Vries, B., Fenhann, J., Gaffin, S., Gregory, K., Grübler, A., Jung, T. Y., Kram, T., La Rovere, E. L., Michaelis, L., Mori, S., Morita, T., Pepper, W., Pitcher, H., Price, L., Riahi, K., Roehrl, A., Rogner, H.-H., Sankovski, A., Schlesinger, M., Shukla, P., Smith, S., Swart, R., van Rooijen, S., Victor, N., and Dadi Z.: IPCC Special Report on Emissions Scenarios: A Special Report of Working Group III of the Intergovernmental Panel on Climate Change, Cambridge University Press, Cambridge, UK, 612, 1-612, 2000.

Semenov, V. A., Latif, M., Dommenget, D., Keenlyside, N. S., Strehz, A., Martin, T., and Park, W.: The Impact of North Atlantic-Arctic Multidecadal Variability on Northern Hemisphere Surface Air Temperature, J. Climate, 23, 5668-5677, 2010.

Wigley, T. M. L., Raper, S. C. B., Hulme, M., and Salmon, M.: Model for the Assessment of Greenhouse-gas Induced Climate Change. UNDP/GEF, NY, USA, 1-52, 2000.

Zhao, M. and Dirmeyer, P.: Production and analysis of GSWP 2 near surface meteorology data sets, COLA Technical Report, Calverton: Center for Ocean-Land-Atmosphere Studies, 159, 136, 2003. 